\title{
Links among Slope Morphology, Canyon Types and Tectonics on Passive and Active Margins in the Northernmost South China Sea
}

\author{
Ho-Shing Yu*, Emmy T Y Chang \\ Institute of Oceanography, National Taiwan University, Taipei
}

\begin{abstract}
We examine slope profile types and variations in slope gradient and slope relief with depth for both passive and active margins in the northern most South China Sea. The passive South China margin is characterized by an exponential slope profile, mainly associated with clustered slope-confined canyons. The active Taiwan margin shows a linear-like shape with great variations along the lower slope. Fewer canyons occur on the Taiwan margin, and hence the influence of canyon incision on slope morphology is relatively less significant. Quantitative analyses of slope curvature, slope gradient and square root of relief variance are useful statistical parameters to explain characteristics and variability of morphology of the slope of the South China margin, but not for the Kaoping slope on the Taiwan side. On the active Taiwan margin, tectonic activities are dominant over sediment deposition and surface erosion, producing a slope profile quite different from those of passive margins of the Middle Atlantic, KwaZulu-Natal, South Africa where failure on slope and accompanying canyon incision are the dominant processes shaping the slope morphology.
\end{abstract}

KEY WORDS: slope morphology, canyon, statistical analysis, continental margin, South China Sea.

\section{INTRODUCTION}

Goff (2001) and Green et al. (2007) demonstrated that types of submarine canyons and canyon-forming processes are closely related to the morphology of continental margins. Submarine canyons on the slopes of New Jersey, Maryland and Virginia in the US Middle Atlantic margin are distinguished from very distinct morphology (Goff, 2001). The dominant canyons on the New Jersey slope show broad and deep heads, indenting the shelf break. The New Jersey slope shows a typical linear profile with average

This study was supported by the National Science Council, Taiwan.

*Corresponding author: yuhs@ntu.edu.tw

Manuscript received October 28, 2008.

Manuscript accepted December 1, 2008. canyon relief decreasing with depth. In contrast, the heads of the Virginia canyons are narrow and shallow and do not indent the shelf break. The Virginia slope is expressed as an exponential profile, steep at the shelf break and decreasing in gradient to the rise. Average canyon relief of the Virginia canyons appears to increase downslope. The Maryland canyons have a mixed morphology; some canyons indent the shelf break and others do not. The profile across the Maryland slope is nearly Gaussian, steepest middle slope and tapering both upslope and downslope. Average canyon relief is approximately constant over most of the Maryland slope. Goff (2001) concluded that the morphology of slope canyons on the US Middle Atlantic margin can be distinguished by the downslope progression of statistical parameters, particularly the average canyon relief.

The quantitative classification of submarine can- 
yons of the US Middle Atlantic margin is considered as the conceptual model for testing links between canyon types and slope morphology. This model was further tested by morphologic and statistical analyses of slope canyons from the northern KwaZulu-Natal passive margin of South Africa (Green et al., 2007). Submarine canyons on the northern KwaZulu-Natal margin are characterized by increasing upslope relief and concave slope-gradient profiles. This morphology is similar to those of canyons of the New Jersey slope. However, two major differences are evident between these two canyon systems. First, the concavity of the northern KwaZulu-Natal slope is in contrast with the nearly linear New Jersey slope. Second, prominent shelf-indenting canyons along the northern KwaZulu-Natal margin are absent. Green et al. (2007) suggested that the slope concavity and absence of shelf-indentation of the northern KwaZulu-Natal canyons may result from a subdued or less intense process of upper slope grading by headward erosion.

These two models provide the motivation for our study to test whether or not a similar relation of canyon types to slope morphology exists for submarine canyons on active and passive margins in the northernmost South China Sea. We hope to add new insights to refine the conceptual models of relating canyon types to morphology of continental margins, the continental slope in particular. This article describes and discusses the slope morphology of both passive and active margins near Southwest Taiwan in terms of steepness, sea floor roughness and shape in profiles.

\section{TECTONIC AND CANYON SETTINGS}

The northern South China Sea narrows towards southwestern Taiwan, becomes shallow and gradually merges into the Taiwan Strait shelf farther north, forming a triangle shape with an open end to the south (Fig. 1). Tectonically, the NE-trending South China margin is a passive rifted margin but the opposite Taiwan margin trending NW represents an active margin with numerous thrust faults and mud diapirs due to the progression of westward compression induced by oblique collision between the South China margin and the Luzon arc (Yu and Huang, 2007; Lallemand and Tsien, 1997). Diapiric intrusions and thrust faults influence the course direction, intensity of incision and morphology of these canyons (Chiang and Yu, 2006; $\mathrm{Yu}$ and $\mathrm{Lu}, 1995)$. Morphologically, the sea floor in the northern South China Sea near Taiwan is mainly covered by two broad slopes: the South China Sea slope to the west and the Kaoping slope to the east. The NS-trending Penghu canyon separates these two juxtaposed continental slopes (Yu and Hong, 2006). Continental slopes are commonly eroded into canyons, channels and smaller gullies (Shepard, 1981). As expected, dozens of unnamed submarine canyons or gullies occur on the slope of the South China margin (Fig. 1). They are mainly slope-confined and closely spaced distributed on the upper slope areas. However, some shallower canyons are found on the lower slope with larger spacing. On the contrary, fewer isolated canyons are present on the Kaoping slope. Three isolated submarine canyons occur on the Taiwan margin: the Kaoping canyon, the largest one, is connected to the river mouth and crosses the narrow shelf and broad slope region, and finally joins the northern Manila trench in a distance of $260 \mathrm{~km}$ (Chiang and Yu, 2006); the Kaohsiung canyon is a very small canyon with a length of about $17 \mathrm{~km}$, occurring on the upper slope and terminating at a water depth of about $700 \mathrm{~m}$ (Yu and Chiang, 1996); and the Fangliao canyon indents the shelf and extends downslope for a length of about $60 \mathrm{~km}$ and ends at a water depth of about $1500 \mathrm{~m}$ (Yu and $\mathrm{Lu}, 1995)$.

\section{DATA AND METHODS}

Bathymetric charts are generated using general mapping tool (GMT) (Wessel and Smith, 1995) to reveal a detailed platform morphology of submarine canyons on both margins. Bathymetric data are drawn from the databank at the National Center for Ocean Research, National Taiwan University (website is http://www.ncor.ntu.edu.tw). Documentation of submarine canyons in the study areas is limited and the data indicate asymmetrical distribution. Submarine canyons on the slope of the South China margin are scarcely studied with little or no background information available. Presently, only eight articles relating to submarine canyons on the Taiwan margin have been published, mainly concerning aspects of morphology and seismic characteristics (e.g., Chiang and Yu, 2006; Liu et al., 1993 and references hereafter). 


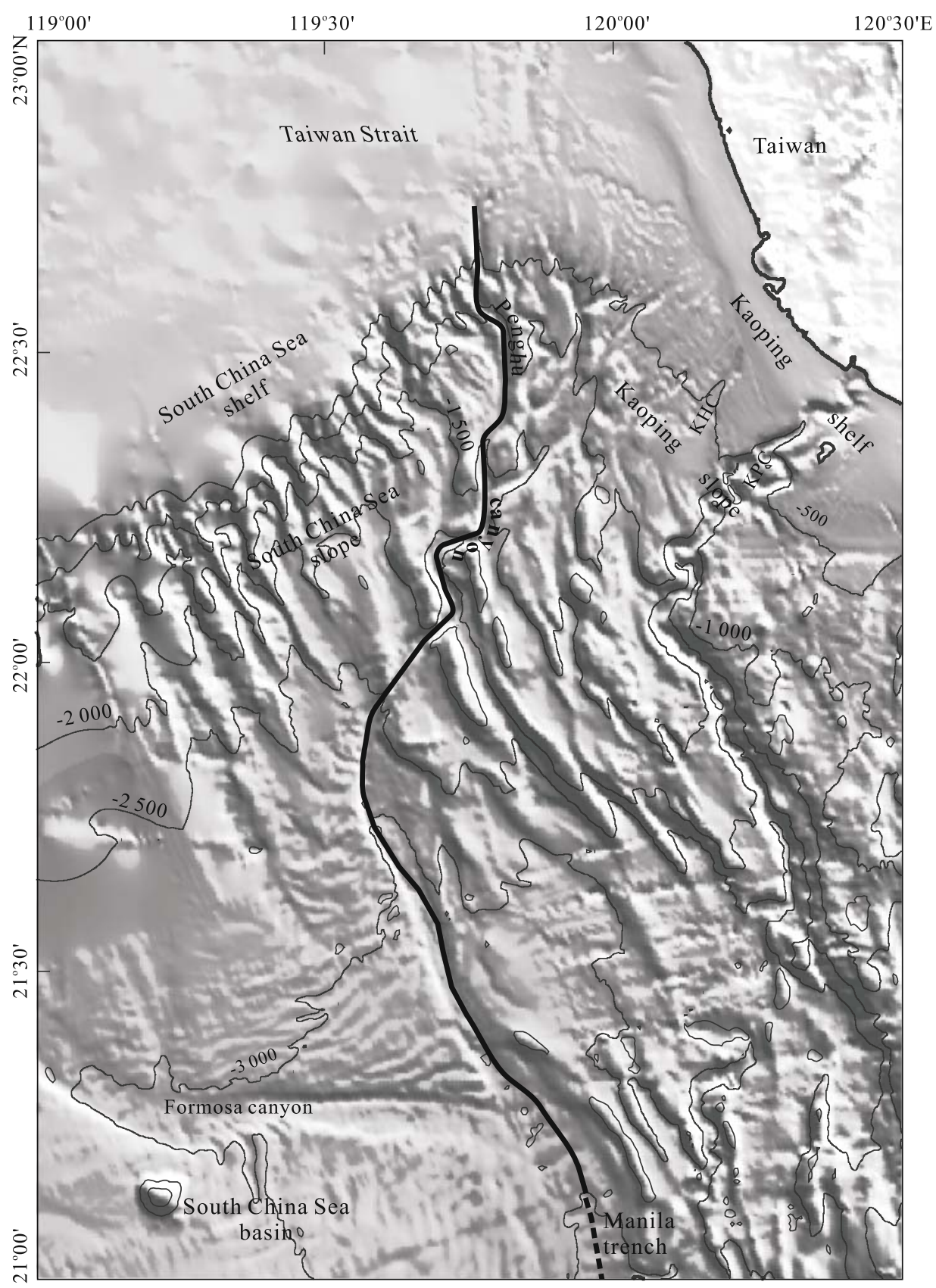

Figure 1. Bathymetric map of the northernmost South China Sea shows juxtaposed passive Chinese margin and active Taiwan margin separated by the NS-trending Penghu submarine canyon. Submarine canyons commonly occur on both continental slopes and incise into the sea floor, producing rugged topography. KHC. Kaohsiung submarine canyon; KPC. Kaoping submarine canyon.

Determinations of slope curvature for both the South China and Taiwan margins were carried out by curve-fitting and visual examination followed the classification of Adams and Schlager (2000). The quantitative analyses of average slope angle and RMS (root-mean-square) relief relating to slope morphology of these two margins are performed, following techniques developed by Goff (2001) and Green et al. (2007). Here the slope angle is evaluated from each profile by the first-order slope morphology. It is computed by taking the arctangent of the difference in mean depth over adjacent profiles divided by the downslope spacing of the profile. The RMS relief determines square root of morphological variance as a function of depth. It measures average variability about the mean value along each profile, estimating the average canyon relief. 

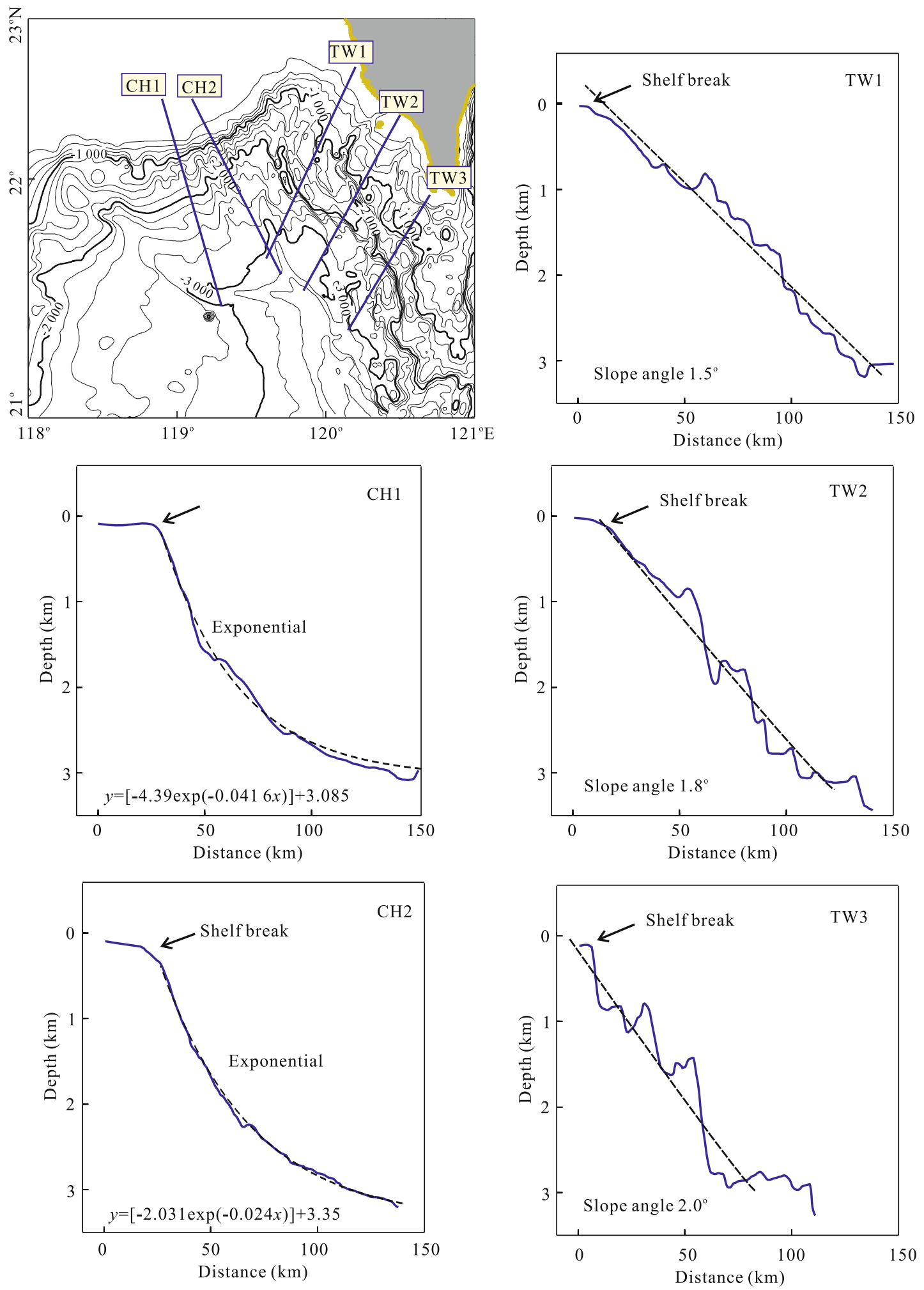

Figure 2. Bathymetric transects across the China margin show exponential profiles of the South China Sea slope below the sharp shelf breaks around $150 \mathrm{~m}$ in water depth. Three bathymetric profiles across the inter-canyon areas of the Kaoping slope on the Taiwan margin display representative linear-like profiles with great deviations. Locations of slope profiles are shown in the upper left box. 


\section{RESULTS}

\section{South China Margin}

Bathymetric map indicates that the South China margin has a relatively flat and wide $(\sim 200 \mathrm{~km})$ shelf and a rugged slope dissected by numerous canyons and gullies (Fig. 1). Bathymetric transects $\mathrm{CH} 1$ and $\mathrm{CH} 2$ across the South China margin show an exponential- curve-fitting profile of the slope below the sharp shelf breaks around $150 \mathrm{~m}$ in water depth (Fig. 2). Profiles $\mathrm{CH} 1$ and $\mathrm{CH} 2$ show that the slopes are concave upward with a definite knick point at the shelf edge, and exponential functions best fit the curvatures of these two slopes.

In terms of RMS relief, the South China margin shows a Gaussian-shaped profile with slope gradients increasing from the shelf break, steep at the middle slope $\left(\sim 4.2^{\circ}\right)$, and decreasing in gradient toward the slope toe (Fig. 3), similar to that of the Maryland slope (Goff, 2001). A large morphological perturbation/ variance occurs at the middle of the canyons. The RMS relief on the slope of the South China margin rapidly increases from the shelf break until it reaches $700 \mathrm{~m}$ water depth on the upper slope, and then gradually decreases to the toe of the lower slope, quite similar to that of the New Jersey pattern (Fig. 3).
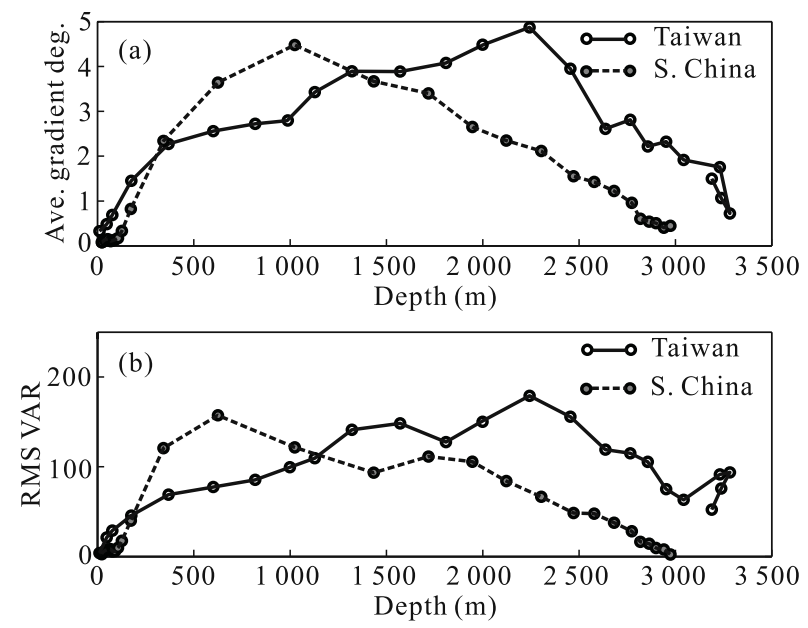

Figure 3. Average downslope gradients for the South China and Taiwan margins plotted versus profile depth (a) and root mean square (RMS) relief measurements for the South China and Taiwan margins plotted versus profile depth (b). Discussion is in the text.

\section{Taiwan Margin}

The Taiwan margin is characterized by a very narrow shelf (less than $20 \mathrm{~km}$ wide) and a slope mainly cut by two noticeable canyons on the upper slope and disturbed by slope-parallel topographic ridges and troughs with greater relief on the lower slope (Fig. 1). Three bathymetric profiles across the inter-canyon areas of the Kaoping slope on the Taiwan margin show that the Kaoping slope has a linear-like profile with great deviations. Noticeable breaks of the slope profiles occur around $1000 \mathrm{~m}$ in water depth where the boundary separating the upper slope from the lower slope occurs (Fig. 2). The Taiwan margin displays a downslope increasing trend of slope gradient with great variations (scatters) until it reaches the lower slope in water depth of $\sim 2250 \mathrm{~m}$ where slope gradient decreases rapidly to the slope toe (Fig. 3). This profile is comparable to none of the profiles of the Middle Atlantic slopes. The RMS relief on the Kaoping slope rapidly increases below the shelf break to a water depth of $\sim 2250 \mathrm{~m}$, and then gradually decreases to the toe of the lower slope, similar to that of the Virginia slope (Fig. 3). The major difference in progression of relief between the Kaoping and Virginia slopes is the location of the sharp decline in relief. The former occurs on the lower slope about 2250 $\mathrm{m}$ water depth while the latter is at the slope/rise break.

\section{DISCUSSION \\ South China Margin}

Unnamed canyons on the South China margin are characterized by relatively small straight courses and densely distributed with their heads restricted to the upper slope (Fig. 1). Considering the forming processes of slope-confined canyons, we suggest that these clustered canyons on the slope of the South China margin resulted mainly from the failure on the slope and subsequent downslope mass movements, leading to erosion of sea floors into an irregular topography. Results of downslope progression of cross-slope statistical parameters of slope gradient and RMS relief provide supporting evidence. The average slope gradient plotted against depth for the South China margin shows that gradient values rapidly increase from shelf to upslope at about $1000 \mathrm{~m}$ water depth, reaching a 
maximum value of about $4.2^{\circ}$, and decreasing in gradient gradually toward the toe of the slope at about $3000 \mathrm{~m}$ water depth. The overall pattern is Gaussian in shape, steepest middle slope around $1000 \mathrm{~m}$ and tapering both upslope and downslope, similar to that of the Maryland slope (Goff, 2001). By analogy, the slope curvature of the slope of the South China margin is mainly shaped by downslope eroding processes and associated erosion of small downslope turbidity currents.

Downslope progression of relief on the slope of the South China margin is similar to that of the New Jersey slope where the headward growth of major canyons graded the upper slope. It means that the retrograde upslope erosion is equally important on forming the canyons, competing erosion with the downslope incision on the slope. Figure 3 suggests that canyons densely developed at the upper slope ( $\sim 150$ to $700 \mathrm{~m}$ water depth) with greater extent of retrograde failure on the upper slope, resulting in an increasing relief trend. Fewer canyons continued to develop at the lower slope, resulting in the progression of RMS relief being decreased downslope.

We tentatively suggest that upslope erosion and downslope incision together initiated and maintained submarine canyons on the slope of the South China margin. Note that the values of RMS relief of the South China margin ranging from a few meters to the maximum of around $150 \mathrm{~m}$ are comparable to those of the Middle Atlantic between 40 to 180 m (Goff, 2001) and those of the KwaZulu-Natal margin ranging from 30 to $170 \mathrm{~m}$ (Green et al., 2007). Although the slope of the South China margin shows similar relief to these two margins of the American Middle Atlantic and South Africa, the canyons on the South China margin may represent an immature stage of canyon evolution because canyons have not indented deeply into the continental shelf. On the other hand, shelf-indenting canyons occur both on the Middle Atlantic and KwaZulu-Natal margins, receiving greater sediment input from the shelf and in turn increasing the intensity of headward erosion into the shelf and reaching a mature stage of canyon incision.

The bathymetric profile of the South China margin is characterized by the convex nature at the shelf break/upper slope transition, forming the steepest slope segment and a concave-upward exponential profile along the rest of the slope (Fig. 2). This may shed light on the explanation of the canyon-forming process. The headward erosion or upslope incision of canyons on the South China margin has not been intense enough to indent into the shelf, and in turn the upper slope has not been graded to reduce its inclination angle, resulting in a convex upward profile immediately below the shelf break. However, the downslope erosion processes shaped the rest of the slope into the exponential slope profile as the sediment transport capacity decreased exponentially with distance from the sediment source at the shelf break, as described by Adams and Schlager (2000).

The degree of canyon incision and sediment input are two useful parameters to differentiate and classify the morphologic variability of passive margins (O'Grady et al., 2000). For example, the New Jersey margins are characterized by great canyon incision and low sediment input, which implies sediment input to continental slope being too low to compensate the sediment removal by canyon erosion, and then resulting in steep and rough slope profiles. By analogy, the steep and rough slopes of the South China margin can be significantly attributed to high canyon incision and low sediment input.

\section{Taiwan Margin}

The slope gradients of the active Taiwan margin show an increasing trend of slope gradient with depth from shelf break to the lower slope (about $2250 \mathrm{~m}$ in water depth) with great scatters, and then decreasing gradually downslope, which is quite dissimilar to those of passive margins of the Middle Atlantic (Goff, 2001) and KwaZulu-Natal, South Africa (Green et al., 2007). This is expected because tectonic activity has great influence on the primary depositional setting of the active continental margins (Adams and Schlager, 2000; Pratson and Haxby, 1996). Three along-dip bathymetric profiles, TW1, TW2 and TW3, across the Taiwan margin (Fig. 2) and the geology of the Kaoping slope are integrated in aiding interpretation of the increasing trend of the slope gradient of the Kaoping slope.

These three slope profiles commonly show a linear-like trend with great irregularities in the lower 
slope ranging from about 1000 to $3200 \mathrm{~m}$ in water depth (Fig. 2). The Kaoping slope is divided into an upper slope and a lower slope at the water depth of about $1000 \mathrm{~m}$ (Yu and Song, 2000; Liu et al., 1998). The slope angle of the upper slope is slightly smaller than that of the lower slope. The former is mainly underlain by several in-filled intra-slope basins bounded by mud diapiric intrusions. The latter is characterized by more and smaller under-filled ponded basins bounded by folds and thrust faults (Yu and Huang, 2007). Some folds and thrust faults form topographic highs on the sea floors with alternating troughs in between.

Adapting the concept of graded slope profile of the Gulf of Mexico where numerous filled intra-slope basins are underlain by the present-day continental slope (Prather et al., 1998), we suggest that the adjustment of slope accommodation space of intra-slope basins of the Kaoping slope tends to reach the ideal graded slope profile, resulting in the present-day slope profile. The sea floor profile of the upper slope represents combined net balance of sediments infilling the intra-slope basins and accompanying downslope mass-wasting processes. The influence of canyon incision on slope gradient is minor. The lower slope is strongly deformed by folds and thrust faults, forming a steeper sea floor profile with underlying smaller ponded basins either empty or partially filled with sediment. We suggest that tectonic activities are dominant over sediment deposition and surface erosion, producing a slope profile quite different from that of the passive margins of the Middle Atlantic and KwaZulu-Natal where failure on slope is the important process shaping the slope morphology.

The progression of relief on the Kaoping slope is comparable to that of the Virginia slope (Fig. 3). However, the mechanisms responsible for the relief on the slopes are quite different. In the Taiwan margin the upper slope and parts of the lower slope are characterized by an increasing trend of relief mainly due to downslope mass-wasting movements but not to canyon incision. Sliding and slumping on the Kaoping slope commonly occur to produce relief on the sea floor (Wu and Liu, 2006). The rugged topography of the lower slope mainly resulted from alternating sea-floor ridges and troughs formed by folds and thrust faulting (Yu and Huang, 2007; Liu et al., 1997). Again, canyon incision plays a role being not as important as tectonic activity to produce relief of the sea floor in the Kaoping slope. On the contrary, the Virginia slope is heavily incised by canyons which are convergent downslope with canyon tributaries (Goff, 2001). Canyon erosion is the most important process for generating relief on the Virginia slope.

In the future work, long-profiles of canyons should be determined and discussed in terms of canyon gradient-area relationship (Mitchell, 2005) to better evaluate the effects of individual sedimentary slope processes on the gross morphology of the continental slopes incised by canyons.

\section{CONCLUSIONS}

The passive South China and active Taiwan margins are characterized by distinct slope morphology (slope curvature, average downslope gradient and RMS relief) and corresponding canyon types (slope-confined, shelf-indenting and river-connected). Quantitative analyses of slope curvature, slope gradient and RMS relief are useful statistical parameters to explain characteristics and variability of morphology of the slope of the South China margin, but not for the Kaoping slope on the Taiwan side. On the active Taiwan margin tectonic activities are dominant over sediment deposition and surface erosion, producing a slope profile quite different from that of passive margins of the Middle Atlantic, KwaZulu-Natal and South China where failure on slope and accompanying canyon incision are the dominant processes shaping the slope morphology.

\section{ACKNOWLEDGMENTS}

Thanks go to the National Center for Ocean Research, National Taiwan University for the use of bathymetric data in the study areas. Prof. J C Chen, Institute of Oceanography, NTU critically reviewed this manuscript. Constructive comments from anonymous reviewers are greatly appreciated.

\section{REFERENCES CITED}

Adams, E. W., Schlager, W., 2000. Basic Types of Submarine Slope Curvature. J. Sed. Res., 70: 814-828

Chiang, C. S., Yu, H. S., 2006. Morphotectonics and Incision of 
the Kaoping Submarine Canyon, SW Taiwan Orogenic Wedge. Geomorphology, 80(3-4): 199-213

Goff, J. A., 2001. Quantitative Classification of Canyon Systems on Continental Slopes and a Possible Relationship to Slope Curvature. Geophy. Res. Lett., 28(23): 4359-4362

Green, A. N., Goff, J. A., Uken, R., 2007. Geomorphological Evidence for Upslope Canyon-Forming Processes on the KwaZulu-Natal Shelf, SW Indian Ocean, South Africa. Geo-Mar. Lett., 27(6): 399-409

Lallemand, S. E., Tsien, H. H., 1997. An Introduction to Active Collision in Taiwan. Tectonophysics, 274(1-3): 1-4

Liu, C. S., Huang, I. L., Teng, L. S., 1997. Structural Features off Southwestern Taiwan. Mar. Geol., 137(3-4): 305-319

Liu, C. S., Liu, S. Y., Lallemand, S., et al., 1998. Digital Elevation Model Offshore Taiwan and Its Tectonic Implications. TAO, 9: 705-738

Liu, C. S., Lundberg, N., Reed, D. L., et al., 1993. Morphological and Seismic Characteristics of the Kaoping Submarine Canyon. Mar. Geol., 111(1-2): 93-108

Mitchell, N. C., 2005. Interpreting Long-Profiles of Canyons in the USA Atlantic Continental Slope. Mar. Geol., 214(1-3): 75-99

O’Grady, D. B., Syvitski, J. P. M., Pratson, L. F., et al., 2000. Categorizing the Morphologic Variability of Siliciclastic Passive Continental Margins. Geology, 28: 207-210

Prather, B. E., Booth, J. R., Steffens, G. S., et al., 1998. Classification, Lithologic Calibration, and Stratigraphic Succession of Seismic Facies of Intraslope Basins, Deep-Water Gulf of Mexico. AAPG Bull., 82: 701-728
Pratson, L. F., Haxby, G. S., 1996. What is the Slope of the U.S. Continental Margin? Geology, 24: 3-6

Shepard, F. P., 1981. Submarine Canyons: Multiple Causes and Long-Time Persistence. AAPG Bull., 65: 1062-1077

Wessel, P., Smith, W. H. F., 1995. New Version of the Generic Mapping Tools Released. EOS Trans. AGU, 76: 329

Wu, C. C., Liu, C. S., 2006. Distribution and Information of Submarine Slides Offshore Southern Taiwan. European Geosciences Union General Assembly, Abstract. Vienna, Austria

Yu, H. S., Chiang, C. S., 1996. Seismic and Morphological Characteristics of the Kaohsiung Submarine Canyon, Southwestern Taiwan. J. Geol. Soc. China, 39(1): 73-86

Yu, H. S., Hong, E., 2006. Shifting Submarine Canyons and Development of a Foreland Basin in SW Taiwan: Controls of Foreland Sedimentation and Longitudinal Sediment Transport. J. Asian Earth Sci., 27(6): 922-932

Yu, H. S., Huang, Z. Y., 2007. Morphotectonics and Sedimentation in Convergent Margin Basins: An Example from Juxtaposed Marginal Sea Basin and Foreland Basin, Northern South China Sea. Tectonophysics, doi: 10.1016/j.tecto. 2007.11.007

Yu, H. S., Lu, J. C., 1995. Development of the Shale Diapir-Controlled Fangliao Submarine Canyon on the Continental Slope off Southwestern Taiwan. J. Asian Earth Sci., 11(4): 265-276

Yu, H. S., Song, G. S., 2000. Submarine Physiographic Features in Taiwan Region and Their Geological Significance. $J$. Geol. Soc. China, 43(2): 267-286 